\title{
SUPRAMOLECULAR DESIGN OF CARBONS FOR ENERGY STORAGE WITH THE REACTANSE-SENSOR FUNCTIONAL HYBRIDITY
}

\author{
I.I. Grygorchak ${ }^{1 *}$, (DA.K. Borisyuk ${ }^{1}$, (DR.Ya. Shvets ${ }^{1}$, \\ (D)D.V. Matulka ${ }^{1}$, (D.I. Grygorchak ${ }^{2}$ \\ ${ }^{1}$ Lviv Polytechnic National University \\ 12 S. Bandera St., Lviv, 79000, Ukraine \\ ${ }^{2}$ Ivan Franko National University of Lviv \\ 1 Universytetska St., Lviv, 79000, Ukraine \\ ${ }^{*}$ E-mail: ivan_gryg@ukr.net
}

Received 23 October 2018, accepted 14 November 2018

The purpose of this work is to expand the class of electrical energy storage devices with non-conjugate functional hybridity. Cyclodextrins of $\beta$ - and $\gamma$-modifications has used as a starting material for research. These materials containing intramolecular voids, which are able to accommodate guest components by molecular recognition on the "lock-key" principle. Methods of precision porometry and impedance spectroscopy has used to study the obtained carbon structures, electrochemical and magnetic measurements has performed to study the obtained carbon structures. Data of the precision porometry has indicated a bimodal porous structure of the synthesized chars. The total specific surface area of active surface of the $\beta$-cyclodextrin carbonizate was about $72 \mathrm{~m}^{2} / \mathrm{g}$. After $\mathrm{KOH}$-modification, the specific capacity for $\beta$-cyclodextrin char was $158 \mathrm{~F} / \mathrm{g}$, and in the negative potential range $203 \mathrm{~F} / \mathrm{g}$. The last value for $\gamma$-cyclodextrin carbon was $162 \mathrm{~F} / \mathrm{g}$. The ability of $\beta$-cyclodextrin to molecular recognition of ferrocene (FC) has used and this cavitat has subjected to activation carbonation according to the same modes as $\beta$-cyclodextrin. The specific capacity of the obtained char of the $\beta$-CD complex after the KOH-modification was $110 \mathrm{~F} / \mathrm{g}$, the specific capacity of the cavitate carbon synthesized on $\gamma$-CD has dropped twice. The study of complexes host-guest inclusions $\beta$-cyclodextrin with molecular iodine has indicated a slight increase of capacity. However, their interface with $30 \%$ aqueous electrolyte solution has shown high photosensitivity. The specific capacitance of the cavitate carbon without $\mathrm{KOH}$-modification has increased four times when it was illuminated with integral and monochromatic light from LEDs of the same intensity. Magnetic studies of the synthesized carbonates have shown that they all demonstrate ferromagnetic properties. Measurement under normal conditions and in a constant magnetic field of cells of symmetric configuration on carbon-based electrodes synthesized with $\gamma$-CD and $\gamma$-CD has showed that their capacitance practically does not change, but their reactance parameters change significantly. Supercapacitors based on these carbonates can serve as sensors of a weak magnetic field at room temperature. Magnetovarionistors is a new class of devices, which are forming on such kind of supercapacitors.

KEYWORDS: supramolecular assemblies, cavitandes, cavitates, nanoporous carbon, porous structure, impedance spectroscopy, Nyquist diagram, photovaricaps

\section{СУПРАМОЛЕКУЛЯРНИЙ ДИЗАЙН КАРБОНІВ ДЛЯ НАКОПИЧУВАЧІВ ЕЛЕКТРИЧНОЇ ЕНЕРГІЇ 3 РЕАКТАНСНО-СЕНСОРНОЮ ФУНКЦІОНАЛЬНОЮ ГІБРИДНІСТЮ \\ І.І. Григорчак ${ }^{1}$, А.К. Борисюк ${ }^{1}$, Р.Я. Швець ${ }^{1}$, Д.В. Матулка ${ }^{1}$, О.І. Григорчак ${ }^{2}$ \\ "Національний університет "Львівська політехніка" 79000, Україна, м. Львів, вул. С. Бандери, 12 \\ 2 Львівський начіональний університет імені Івана Франка 79000, Україна, м. Львів, вул. Університетська, 1}

Метою даної роботи $є$ розширення класу накопичувачів електричної енергії 3 неспряженою функціональною гібридністю. В якості вихідної речовини для досліджень використано циклодекстрини $\beta$ - та $\gamma$ - модифікацій, які містять внутрімолекулярні пустоти, які здатні акомодувати гостьові компоненти шляхом молекулярного розпізнавання за принципом “замок- ключ”. Для досліджень отриманих карбонових структур використали методи прецизійної порометрії та імпедансної спектроскопії, проведено електрохімічні та магнітні вимірювання. Дані прецизійної порометрії засвідчили про бімодальну пористу структуру синтезованих карбонізатів. Загальна питома площа активної поверхні $\beta$-циклодекстринового карбонізату становила порядка $72 \mathrm{~m}^{2} / \Gamma$. Після КОН-модифікації питома ємність для $\beta$-циклодекстринового карбонізату становила $158 \Phi /$, а у від'ємній області потенціалів - $203 \Phi /$. Для $\gamma$-циклодекстринового карбону остання величина становила - 162 Ф/г. Використовуючи здатність $\beta$-циклодекстрину до молекулярного розпізнавання фероцену (FC) цей кавітат піддано активаційній карбонізації за тими ж режимами, що і $\beta$-циклодекстрин. Питома ємність отриманого карбонізату комплексу $\beta$ - $\mathrm{CD}<\mathrm{FC}>$ після $\mathrm{KOH-модифікації} \mathrm{становила} 110$ Ф/г. Для кавітатного карбону, синтезованого $з$ $\mathrm{CD}<\mathrm{FC}>$ питома ємність впала у два рази. Дослідження $\beta$-циклодекстрин комплексів включень “господар-гість” 3 молекулярним йодом, вказали на незначне зростання ємності. Проте їх межа 330 \%-водним розчином електроліту проявила високу фоточутливість. При освітленні інтегральним і монохроматичним світлом від світлодіодів однакової інтенсивності питома ємність кавітатного карбону без КОН-модифікації зросла в 4 рази. Магнітні дослідження синтезованих карбонів показали, що усі вони проявляють феромагнітні властивості. Вимірювання комірок симетричної конфігурації з електродами на основі карбонів, синтезованих з $\gamma$-CD та $\gamma$-CD $<\mathrm{FC}>$ за нормальних умов та в постійному магнітному полі показали, що їх ємність практично не міняється, зате суттєво змінюються їх реактансні параметри. Суперконденсатори на основі цих карбонів можуть служити давачами слабкого магнітного поля за кімнатних температур, формуючи новий клас пристроїв магнетоваріоністорів. 
КЛЮЧОВІ СЛОВА: супрамолекулярні ансамблі, кавітанди, кавітати, нанопористий карбон, пориста структура, імпедансна спектроскопія, діаграма Найквіста, фотоварікапи

\author{
СУПРАМОЛЕКУЛЯРНЫЙ ДИЗАЙН КАРБОНОВ ДЛЯ НАКОПИТЕЛЕЙ ЭЛЕКТРОЭНЕРГИИ С \\ РЕАКТАНСНО-СЕНСОРНОЙ ФУНКЦИОНАЛЬНОЙ ГИБРИДНОСТЬЮ \\ И.И. Григорчак ${ }^{1}$, А.К. Борисюк ${ }^{1}$, Р.Я. Швец ${ }^{1}$, Д.В. Матулка ${ }^{1}$, О.И. Григорчак ${ }^{2}$ \\ ${ }^{1}$ Национальный университет "Львовская политехника", \\ 79000, Украина, г. Львов, ул. С. Бандеры, 12 \\ ${ }^{2}$ Львовский национальный университет имени Ивана Франко \\ 79000, Украина, г. Львов, ул. Университетская, 1
}

Целью данной работы является расширение класса накопителей электрической энергии с несопряженной функциональной гибридностью. В качестве исходного вещества для исследований использованы циклодекстрины $\beta$ - и $\gamma$ - модификаций, содержащие внутримолекулярные пустоты, которые способны аккомодировать гостевые компоненты путем молекулярного распознавания по принципу "замок-ключ". Для исследований полученных карбоновых структур использовали методы прецизионной порометрии и импедансной спектроскопии, проведено электрохимические и магнитные измерения. Данные прецизионной порометрии свидетельствовали о бимодальной пористой структуре синтезированных карбонизатов. Общая удельная площадь активной поверхности $\beta$-циклодекстринового карбонизата составляла порядка $72 \mathrm{~m}^{2} / \Gamma$. После КОНмодификации удельная емкость для $\beta$-циклодекстринового карбонизата составляла $158 \Phi / г$, а в отрицательной области потенциалов - 203 Ф/г. Для $\gamma$-циклодекстринового карбона последняя величина составила - 162 Ф/г. Используя способность $\beta$-циклодекстрина до молекулярного распознавания ферроцена (FC) этот кавитат подвергнуто активационной карбонизации по тем же режимам, что и $\beta$-циклодекстрин. Удельная емкость полученного карбонизата комплекса $\beta$-CD $<\mathrm{FC}>$ после $\mathrm{KOH}$ модификации составляла $110 \Phi /$. Для кавитатного карбона, синтезированного с $\gamma$-CD $<\mathrm{FC}>$ удельная емкость упала в два раза. Исследование $\beta$-циклодекстрин комплексов включений "хозяин-гость" с молекулярным йодом, указали на незначительный рост емкости. Однако их граница с $30 \%$-водным раствором электролита проявила высокую фоточувствительностью. При освещении интегральным и монохроматическим светом от светодиодов одинаковой интенсивности удельная емкость кавитатного карбона без КОН-модификации возросла в 4 раза. Магнитные исследования синтезированных карбонов проявили, что все они проявляют ферромагнитные свойства. Измерение ячеек симметричной конфигурации с электродами на основе карбона, синтезированных с $\gamma$-CD и $\gamma$-CD $<\mathrm{FC}>$ при нормальных условиях и в постоянном магнитном поле показали, что их емкость практически не меняется, однако существенно изменяются их реактансные параметры. Суперконденсаторы на основе этих карбонов могут слугувать датчиками слабого магнитного поля при комнатных температурах, формируя новый класс устройств - магнетоварионисторы.

КЛЮЧЕВЫЕ СЛОВА: супрамолекулярные ансамбли, кавитанды, кавитаты, нанопористый карбон, пористая структура, импедансная спектроскопия, диаграмма Найквиста, фотоварикапы

Сьогоднішній бурхливий розвиток електромобілебудування й альтернативної енергетики, вражаючі успіхи наноелектроніки та спінтроніки актуалізували задачу забезпечення функціональної гібридності відповідних пристроїв, яка виходить на чільне місце на шляху створення новітніх схемотехнічних рішень. В означеному ракурсі найбільш широко вивчалися електрохімічні конденсатори, які об'єднували в собі механізми ємнісного та псевдоємнісного накопичення енергії [1], що дозволяє досягати великої питомої енергії [2-5]. Наприклад, нами в роботах [6-7] встановлений зворотний заряд нанопористого карбону до 2000 Ф/г, заснований на процесі електросорбції аніонів I- при электродних потенціалах, що не досягають потенціалу виділення йоду у вільному стані та потенціалу утворення $\mathrm{I}_{3}^{-}$. Таке сильне (практично десятикратне) зростання диференціальної псевдоємності порівняно з максимально можливим значенням відповідної величини для нефарадеєвських процесів зумовлене розблокуванням межі розділу з електролітом щодо інтеркаляційної псевдоємності при певному критичному потенціалі. При ньому впровадження йона 3 електроліту у карбон відбувається, коли енергія сольватації в твердому тілі не перевищуватиме значення його хімічного потенціалу в електроліті. У роботі [8] нами запропонований новий підхід до розблокування "ідеально" поляризовуваної межі поділу нанопористого вуглецю з електролітами, який полягає не у підборі параметрів фаз і величин прикладених потенціалів, а у модифікації енергетичного спектру шляхом ієрархізації його структури при формуванні кавітандного ансамблю C<18-краун-6>. В результаті забезпечується функціональна гібридність: в інтервалі

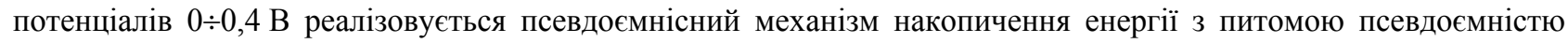
$\sim 13350$ Ф/Г, а при 0,4 1,2 В - ємнісний механізм ( 80 Ф/г). При цьому, ультразвукове опромінення призводить до росту струмів обміну на міжфазній межі супрамолекулярних ансамблів і до $20 \%$ росту густини накопиченого заряду.

Означену вище функціональну гібридність можна умовно назвати як функціонально-спряженою, оскільки обидві здатності відносяться до однотипних процесів - накопичення електричної енергії, хоч і за принципово різними механізмами i, відповідно, різними значеннями експлуатаційних параметрів. Слід відзначити, що в останньому випадку такий перехід до іншого механізму процесів часто супроводжується погіршенням параметрів. Так, псевдоємнісний механізм накопичення енергії передбачає зниження кількості циклів “заряд розряд", та максимальну потужність електрохімічних псевдоконденсаторів.

Видається, більшу зацікавленість може викликати функціонально неспряжена гібридність. Прикладом якої може служити наша рання робота [9], в якій був створений суперконденсатор на основі спеціально синтезованого карбонового композиту, який при адіабатичному розряді забезпечував охолодження. На жаль, 
інші роботи такого напряму нам не відомі. Тому метою цієї статті $є$ розширення класу накопичувачів електричної енергії зі неспряженою функціональною гібридністю.

\section{КОНЦЕПТУАЛЬНІ ПОЛОЖЕННЯ І МЕТОДИКА ЕКСПЕРИМЕНТУ}

Ми припустили, що досягнення поставленої мети можна добитися застосуванням в процесах енергонакопичення третього основного виду організації речовин - клатратного (або супрамолекулярного) 3 огляду на його структурно-енергетичні особливості $[10,11]$. Це може призвести не тільки до принципово нових закономірностей міжфазного перенесення заряду, але і високоефективного ємнісного накопичення енергії. Водночас, слід відзначити, що застосовувана сьогодні вихідна сировина для синтезу активованого вугілля має будову, яка не може акомодувати у своїй внутрішній мікроструктурі певні легуючі речовини, які би уже на стадії карбонізації регулювали електронну будову отримуваного нанопористого карбону. Тому виходячи саме 3 цих міркувань, а також враховуючи потреби екологічної безпеки та дешевизни, в роботі в якості вихідної сировини вибрані циклодекстрини $\beta$ - та $\gamma$ - модифікацій (рис. 1), які містять внутрімолекулярні пустоти, в які можуть бути акомодовані гостьові компоненти шляхом молекулярного розпізнавання за принципом “замокключ” [11]. Існуюча ще $\alpha$-модифікація циклодекстрину не розглядалася через проблему її стабільності.

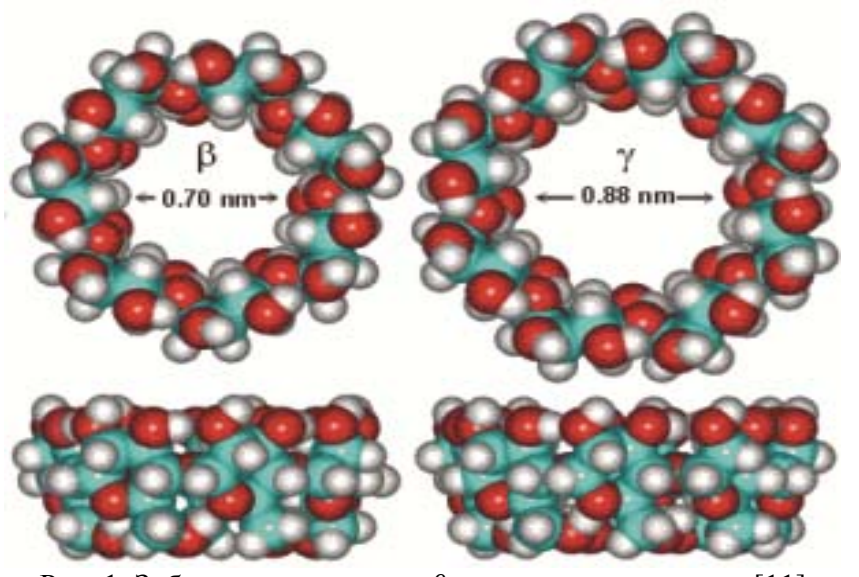

Рис. 1. Зображення молекул, $\beta$ - та $\gamma$-циклодекстрину [11]

Пориста будова отриманих карбонових структур була визначена методами прецизійної порометрії 3 використанням порометра ASAP 2000 М.

Електрохімічні виміри проводили за дво- і триелектродною схемами 3 хлор-срібним електродом порівняння. Для цього досліджувані матеріали зі зв’язуючим агентом (5 \% полівіліденфторид) напресовувалися на нікелеву сітку площею $0,5 \mathrm{~cm}^{2}$. Маса активного матеріалу не перевищувала 3 мг. В якості електроліту використовували $30 \%$ водний розчин $\mathrm{KOH}$. Електродні потенціали $E$ перераховувалися відносно стандартного водневого електроду порівняння.

Імпедансні спектри (в діапазоні частот $5 \times 10^{-3}-10^{5}$ Гц з амплітудою $5 \mathrm{mB}$ ) в потенціостатичних умовах, циклічні вольтамперограми і гальваностатичні заряд-разрядні цикли записані за допомогою вимірювального комплекса “AUTOLAB” фірми “ECO CHEMIE” (Голандія), укомплектованого комп”ютерними програмами FRA-2 та GPES. Видалення сумнівних точок проводилося фільтром Дирихле $[12,13]$. Частотні залежності комплексного імпедансу Z аналізувалися графоаналітичним методом в середовищі програмного пакету ZView 2.3 (Scribner Associates). Похибки апроксимації не перевищували $4 \%$. Адекватність побудованих імпедансних моделей пакету експериментальних даних була підтверджена повністю випадковим характером частотних залежностей залишкових різниць першого порядку $[12,13]$. Значення ємностей для побудови вольт-фарадних залежностей визначалися з точністю 2 - 8\% (Крамерс-Кроніг тест був в межах $10^{-6}-10^{-5}$ ).

Магнітні вимірювання виконували за допомогою магнітометра з вібруючим зразком [14].

\section{РЕЗУЛЬТАТИ ТА ЇХ ОБГОВОРЕННЯ \\ Кавітандні циклодекстринові карбони}

Особливістю циклодекстринів, як сировини для отримання активованого вуглецю, є сильне спінювання при нагріванні в результаті процесів дегідратації та виділення діоксиду вуглецю, котре супроводжується багатократним (десятки разів) збільшенням об’єму, що вимагає особливого режиму піролізу [15]. Тому застосовували наступний режим приготування зразків: нагрівання зі швидкістю $1{ }^{\circ} \mathrm{C} / \mathrm{xв}$ до $100{ }^{\circ} \mathrm{C}$ i витримка для видалення води протягом 2 год., стабілізаційна обробка при температурі $500{ }^{\circ} \mathrm{C}$ протягом 5 год., карбонізація при $800{ }^{\circ} \mathrm{C}$ протягом 4 год. Отриманим частинкам карбонізату властива порожнинна структура. При цьому розміри частинок карбонізату $\gamma$-циклодекстрину значно менші, ніж аналогічні $\beta$-циклодекстрину, $\mathrm{i}$ порожнини у них менші (рис. 2). Рентгеноспектральний аналіз показав практично чисто карбонову фазу отриманого продукту. 
Хімічна КОН-активація при температурі $800{ }^{\circ} \mathrm{C}$ упродовж 2 годин призводить до значного зменшення частинок активованого вугілля порівняно з вихідними.
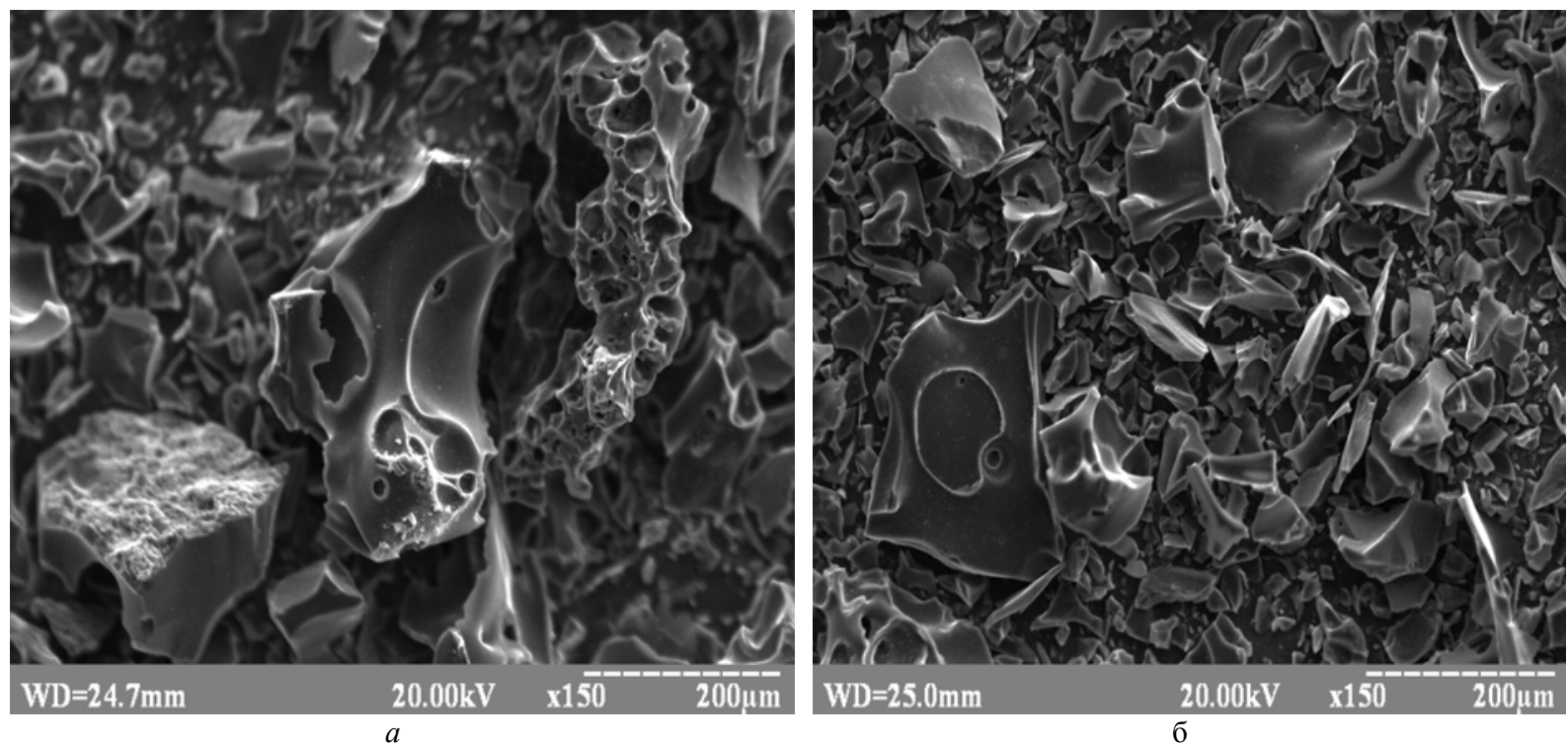

Рис. 2. Електрономікросопічне зображення нанопористого карбону, отриманого активаційною карбонізацією $\beta$-циклодекстрину (а) та $\gamma$-циклодекстрину (б)

Дані прецизійної порометрії, опрацьовані методом DFT свідчать про бімодальну пористу структуру синтезованих карбонізатів 3 максимумами в розподілі пор за їхніми діаметрами в околі 1,3 та 4,3 нм (рис. 3). Загальна питома площа активної поверхні $\left(\mathrm{S}_{\text {акт }}\right) \beta$-циклодекстринового карбонізату порядка $72 \mathrm{м}^{2} / \Gamma$. Активація водяною парою забезпечує питому ємність 50 Ф/г в симетричній конфігурації. Після КОН-модифікації вона в даній геометрії вимірів зростає до 158 Ф/г, а у від’ємній області потенціалів - від 101 до 203 Ф/г. Для $\gamma$ циклодекстринового карбону з практично “ідеальними” гальваностатичними циклами “заряд - розряд” (рис. 4) остання величина має дещо менше значення - 162 Ф/г. Порівнюючи це значення з питомою площею поверхні знаходимо, що диференціальна ємність даного вуглецю складає 22 мкФ/см². За наявними літературними даними [16] ця величина є вищою від відповідного параметру більшості відомих видів активованого вугілля, що використовуються в суперконденсаторах. Фізична причина цього найімовірніше зумовлена тим, що в такому матеріалі є висока густина станів на рівні Фермі, яка сприяє екрануванню адсорбованих зарядів, що формують подвійний електричний шар (ПЕШ). Неочікуваним фактом стало те, що ультразвукове опромінення також значно ( 5 разів) збільшує площу активної поверхні і більш суттєвіше навіть ніж КОН-модифікація розширює об'єм мезопор. Для обидвох матеріалів виявлений однотипний - ємнісний характер кінетики накопичення енергії на межі їх розділу з електролітом.

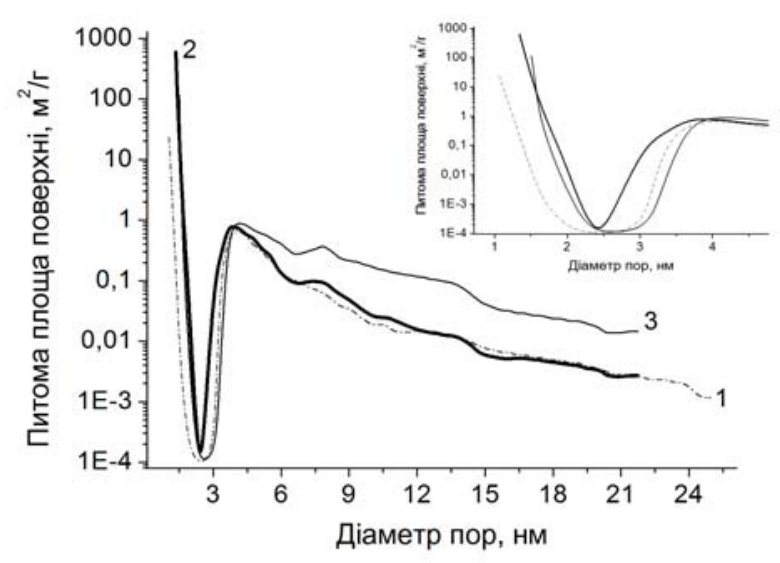

Рис. 3. Розподіл площі пор за їхнім діаметром $\beta$ циклодекстринового карбону:

1 - до КОН-модифікації, 2 - після КОН-модифікації, 3 - після ультразвукового опромінення

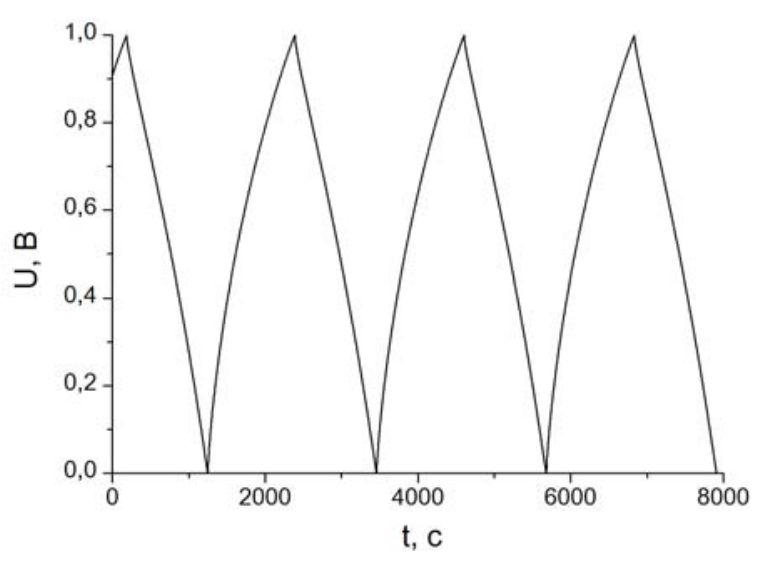

Рис. 4. Гальваностатичні цикли “заряд-розряд” для кавітандного карбону, синтезованого 3 -циклодекстрину 


\section{Кавітатні циклодекстринові карбони}

За загальною технологічною схемою кавітатні карбони синтезуються шляхом "pre"-модифікації вихідного кавітандного ансамблю гостьовим контентом 3 наступними активаційною карбонізацією та "post"-хімічною (фізичною) модифікаціями. Використовуючи здатність $\beta$-циклодекстрину до молекулярного розпізнавання фероцену (FC) [17], який відомий, як один з найбільш електрохімічно зворотніх електродних матеріалів, нами насамперед цей кавітат був підданий активаційній карбонізації за тими ж режимами, що і $\beta$-циклодекстрину. Оскільки фероцен нерозчинний у воді, метод співкристалізації з водного розчину, котрий широко застосовується 3 водорозчинними сполуками, не може бути застосований. Для отримання комплексів "господар-гість" використовували метод прямого додавання тонких фероценових кристалів до водного розчину $\beta$ - i $\gamma$ - CD при температурі $60^{\circ} \mathrm{C}$ з перемішуванням та наступним випаровуванням [18]. Комплекси $\epsilon$ стехіометричними і мають співвідношення господаря і гостя для $\beta$ - i $\gamma$ - $\mathrm{CD}-1: 1$. Внаслідок самоорганізації можуть формуватися супрамолекулярні ансамблі за типом молекулярного намиста, ланка якого показана на вставці до рис. 5.

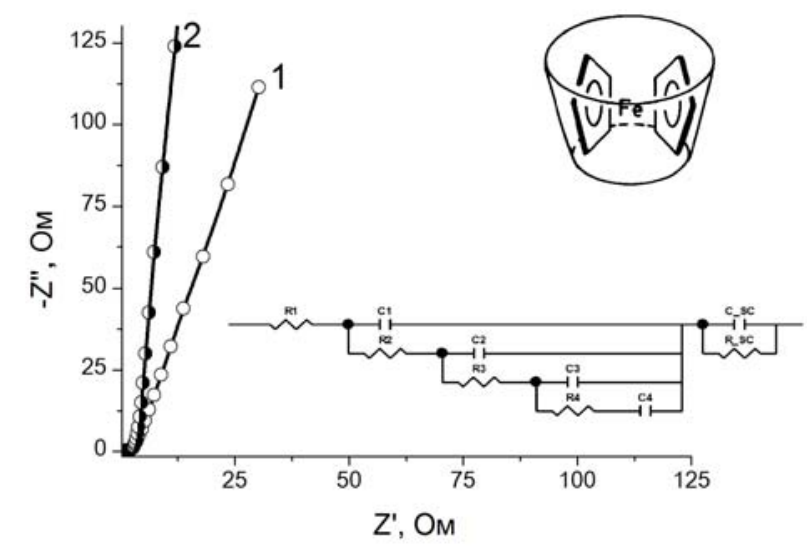

Рис. 5. Діаграми Найквіста для карбону, синтезованого з $\gamma$-CD (1) та $\gamma$-CD $<$ FC $>(2)$

На вставках - ланка молекулярного намиста $3 \gamma$-CD $<$ FC $>$ [18] та заступна електрична схема
Частинки карбонізату комплексу $\beta$ - $\mathrm{CD}<\mathrm{FC}>$ теж містять порожнини, але значно менші і в меншій кількості, ніж отриманого $3 \beta$-CD. Їх питома ємність в симетричній комірці з $30 \%$ водним розчином $\mathrm{KOH}$ не перевищувала 40 Ф/г. Після КОН-модифікації вона в даній геометрії вимірів зростає до $110 \Phi / Г$, а у від'ємній області потенціалів досягає 145 Ф/Г при відмінній кулонівській ефективності $99 \%$. Для кавітатного карбону, синтезованого з $\gamma$-CD $<\mathrm{FC}>$ питома ємність падає у два рази, що найімовірніше пов'язано 3 різною комплементарністю фероцену до обидвох матриць. 3 даних на рис. 5 можна зробити висновок, що кавітатизація прекурсору для активаційної карбонізації покращує параметри ємнісного накопичення заряду, в даному разі суттєво зменшує тангенс кута електричних втрат. Спостережуваний ємнісний механізм накопичення енергії, добре моделюється еквівалентною електричною схемою де Леві, яка модифікована, у відповідності до підходу Войта, послідовним приєднанням паралельної $\mathrm{R}_{\mathrm{SC}} \mathrm{C}_{\mathrm{SC}}$ - ланки (вставка до рис. 5). Тут $\mathrm{R}_{\mathrm{SC}}$ і $\mathrm{C}_{\mathrm{SC}}$ - відповідно опір і ємність області просторового заряду.

Добре відомо, що $\beta$-циклодекстрин утворює комплекси включення “господар-гість” і з молекулярним йодом [19], в яких йод існує в полімолекулярній формі. Висока електронна густина усередині порожнини $\beta-C D$ може активувати електрони молекул “гостей”, що призводить до зміни спектральних властивостей як включених молекул, так і самих $\beta$-CD. Комплексоутворення з $\beta$ - $C D$ може помітно змінювати початковий спектр поглинання молекул. Це означає, що при використанні такого кавітатного комплексу в процесі активаційної карбонізації матимемо ситуацію, при якій карбонізується прекурсор зі зміненою електронною структурою порівняно 3 вихідним рецептором (без субстрату). Очевидно, що і синтезований карбон матиме інші властивості. I дійсно, як було нами встановлено в [20], для сульфат-залізного субстрату зафіксоване зростання питомої ємності більш як на $50 \%$. У нашому випадку полійодистого субстрату зростання ємності для відповідного нанопористого карбону (після аналогічної "post"-модифікації) $є$ меншим і складає $10 \%$. Проте він набуває неординарних неочікуваних властивостей - його межа з $30 \%$-водним розчином електроліту проявляє високу фоточутливість.

\section{Фоточутливість супрамолекулярних карбонів. Фотоваріоністори.}

На рис. 6 наведені діаграми Найквіста і зміна ємності симетричної системи з супрамолекулярно "pre-post" модифікованим нанопористим карбоном (КНК): КНК || $30 \% \mathrm{KOH}\left(\mathrm{H}_{2} \mathrm{O}\right)||$ КНК при освітленні як інтегральним, так і монохроматичним світлом від світлодіодів однакової інтенсивності. Тут цікаво зазначити, що без КОНмодифікації дана система характеризується ще вищою фоточутливістю: питома ємність на світлі зростає більш як в 4 рази. Однак в цьому разі годографи імпедансу вказують скоріше на псевдоємнісний механізм накопичення енергії, ніж на ємнісний (рис. 7). В результаті, в останній ланці модифікованої схеми де Леві (вставка до рис. 5) конденсатор $\mathrm{C}_{4}$ необхідно замінити елементом закритого Варбургу $\left(\mathrm{W}_{\mathrm{s}}\right)$. Це $\epsilon$ своєрідний сонячний суперконденсатор, що характеризується цікавою кінетикою, для якої властивий дифузійний контроль.

Механізм гігантського зростання ємності при освітленні може бути зрозумілим з наступної моделі. При сильно розвиненій поверхні матеріалу можемо зустрітися з двома випадками: 1) фрагменти матеріалу між порожнинами $\epsilon$ ще достатньо великі, щоб не враховувати квантоворозмірні ефекти; 2) фрагменти матеріалу де- 
факто стають 2-, 1- чи 0-вимірними об'єктами. У кожному з цих випадків при заряджанні такого матеріалу ми можемо мати справу з ситуацією, коли кількість заряду, який знаходиться на активній поверхні, є більша, ніж може бути ефективно зекранована вільними носіями матеріалу. Це приводитиме до зростання довжини екранування i, відповідно, до зростання ефективної відстані між зарядами з обох сторін активної поверхні i зменшення геометричної ємності матеріалу. Іншими словами, ми матимемо справу з шунтуючою квантовою ємністю. Хоча у першому і другому випадку природа описаного явища та сама, а саме: зменшення густини станів порівняно 3 неперервним середовищем, однак спосіб теоретичного опису дещо інший. Розглянемо спочатку загальні формули, а потім кожен з випадків окремо.
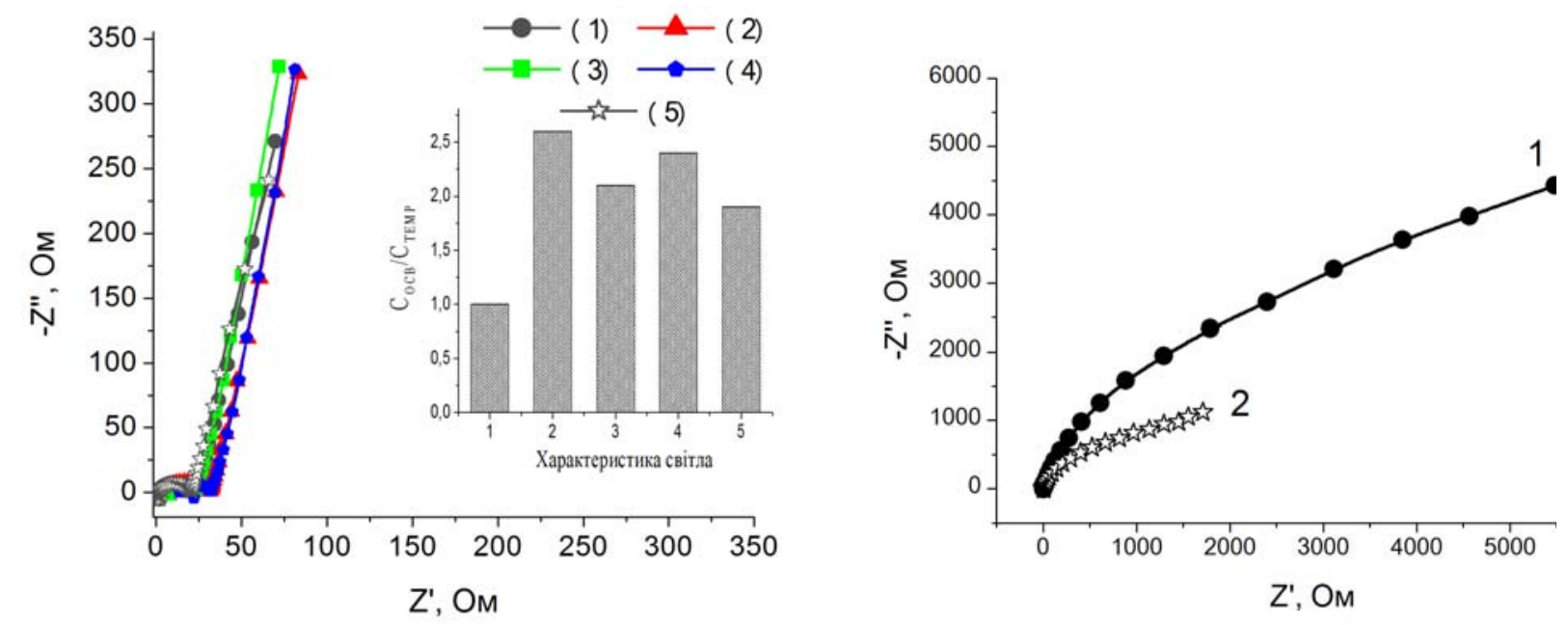

Рис. 6. Діаграми Найквіста для карбону, синтезованого з $\beta$-CD $<\mathrm{J}_{2}>$ в темряві (1) та при освітленні однакової інтенсивності червоним (2), зеленим (3), синім (4) та інтегральним світлом (5)

Рис. 7. Діаграми Найквіста, побудовані для вимірів в темряві (1) та при освітленні (2)

Приріст енергії подвійного шару при додаванні елементарного заряду матиме вигляд:

$$
e \delta V=\frac{e^{2} d}{\varepsilon \varepsilon_{0}} \delta n+\delta \mu,
$$

де перший доданок відображає збільшення енергії, пов'язаної з геометричною ємністю подвійного шару, а другий, - зміна хімпотенціалу, - пов'язаний з внеском в енергію від квантової ємності, $\delta n-$ зміна концентрації заряду на активній поверхні.

Величину $\delta \mu$ можемо записати так:

$$
\delta \mu=\frac{\partial \mu}{\partial n} \delta n
$$

Тоді

$$
e \delta V=\frac{e^{2}}{\varepsilon \varepsilon_{0}}(d+\lambda) \delta n,
$$

де довжина екранування $\lambda$ рівна:

$$
\lambda=\frac{1}{e^{2}} \frac{\partial \mu}{\partial n} .
$$

I остаточно

$$
C=\frac{S e \delta n}{\delta V}=\frac{S}{\varepsilon_{0} \varepsilon(d+\lambda)} .
$$

Випадок, коли немає необхідності враховувати квантово-розмірні ефекти також розбивається на два, в залежності від концентрації електронів у зоні провідності матеріалу. Розглянемо випадок низької концентрації електронів в зоні провідності. Тоді ми маємо справу з класичним електронним газом, оскільки температура виродження $T_{0}=\frac{\hbar^{2}}{m} n^{\frac{2}{3}}$ буде низькою. Хімпотенціал класичного електронного газу має вигляд: 


$$
\mu=k T\left[n\left(\frac{2 \pi \hbar^{2}}{m k T}\right)^{\frac{2}{3}}\right] .
$$

Тоді

$$
\lambda=\frac{k T}{e^{2} n}=\frac{k T}{e^{2} \alpha n_{0}} .
$$

Під концентрацією $n$ ми розуміємо $n=\alpha n_{0}$, де $n_{0}$ - це концентрація електронів у зоні провідності непористого матеріалу, а $\alpha<1$ - це феноменологічний коефіцієнт, пропорційний до величини одиниці мінус пористість матеріалу.

Таким чином, наявність пор зменшує концентрацію електронів і збільшує довжину екранування, що веде до зменшення сумарної ємності матеріалу.

У випадку високої концентрації електронів, коли температура виродження є високою, ми будемо мати справу з виродженим електронним газом, для якого хімпотенціал має вигляд:

$$
\mu=\frac{\hbar^{2}}{8 m}\left(\frac{3 n}{\pi}\right)^{\frac{2}{3}}\left[1-\frac{\pi^{2}}{12}\left(\frac{\hbar^{2}}{8 k T m}\left(\frac{3 n}{\pi}\right)^{\frac{2}{3}}\right)^{-2}+\ldots\right] .
$$

Використаємо лише перший, ведучий, член розкладу. Тоді, з урахуванням вищесказаного

$$
\lambda=\frac{\hbar^{2} n^{-\frac{1}{3}}}{12 m e^{2}}\left(\frac{3}{\pi}\right)^{\frac{2}{3}}=\frac{\hbar^{2}\left(\alpha n_{0}\right)^{-\frac{1}{3}}}{12 m e^{2}}\left(\frac{3}{\pi}\right)^{\frac{2}{3}} .
$$

Бачимо, що, як у випадку малих концентрацій, так і у випадку високих, якісно картина залишається тією самою, лише у другому випадку залежність від концентрації і пористості є значно меншою.

При освітленні кількість електронів у зоні провідності зростає, а відповідно довжина екранування повинна зменшуватися і загальна ємність рости. У випадку простої моделі наявності одного домішкового рівня, об’ємну концентрацію електронів у зоні провідності, спричинену впливом світла і температурою, можна знайти 3 рівняння:

$$
\frac{\partial n}{\partial t}=\gamma m \bar{n}_{0} \exp \left(-\frac{\Delta E}{k T}\right)-\gamma n p+\gamma_{l} \Phi+\frac{1}{q} \frac{\partial j}{\partial x},
$$

яке для стаціонарного випадку:

$$
\frac{\partial n}{\partial t}=0, j=0, \frac{\partial j}{\partial x}=0
$$

набуде вигляду

$$
\gamma m \bar{n}_{0} \exp \left(-\frac{\Delta E}{k T}\right)-\gamma n p+\gamma_{l} \Phi=0
$$

Звідси

$$
n=\frac{\gamma m \bar{n}_{0} \exp \left(-\frac{\Delta E}{k T}\right)+\gamma_{l} \Phi}{\gamma p} .
$$

У написаних вище формулах використані такі позначення: $\gamma$ - коефіцієнт рекомбінації, $\gamma_{l}$ - коефіцієнт світлової генерації, $\Phi$ - світловий потік, $\bar{n}_{0}$ - концентрація електронних станів поблизу дна зони провідності, $\Delta E$ - відстань домішкового рівня від дна зони провідності, $k$ - стала Больцмана, $T$ - абсолютна температура, $E$ - напруженість електричного поля, $q$ - заряд електрона, $\varepsilon$ - діелектрична стала. Отже, величина $\gamma m \bar{n}_{0} \exp \left(-\frac{\Delta E}{k T}\right)$ відповідає за теплову генерацію, $\gamma_{l} \Phi$ - за світлову, $p$ - концентрація дірок, а $m-$ концентрація електронів на домішковому рівні, $\gamma n p$ - рекомбінаційний член.

Якщо вважати, що у попередніх моделях вже врахований внесок від теплової генерації в концентрацію електронів у зоні провідності, то надлишкова концентрація електронів, спричинена виключно освітленням, матиме вигляд: 


$$
\Delta n=\frac{\gamma_{l} \Phi}{\gamma p}
$$

Тоді у двох попередніх випадках для довжини екранування будемо мати формули:

$$
\begin{gathered}
\lambda=\frac{k T}{e^{2} n}=\frac{k T}{e^{2}\left(\alpha n_{0}+\frac{\gamma_{l} \Phi}{\gamma p}\right),} \\
\lambda=\frac{\hbar^{2}\left(\alpha n_{0}+\frac{\gamma_{l} \Phi}{\gamma p}\right)^{-\frac{1}{3}}}{12 m e^{2}}\left(\frac{3}{\pi}\right)^{\frac{2}{3}},
\end{gathered}
$$

чим і пояснюється зменшення довжини екранування (і відповідно збільшення ємності) при освітленні.

Випадок, коли є необхідність враховувати квантово-розмірні ефекти припустимо, що пористий матеріал влаштований так, що поза межами пор він являє собою двовимірну систему. Тоді, як відомо, довжина екранування, без врахування електрон-електронної взаємодії, не залежатиме від концентрації:

$$
\lambda=\frac{\pi \hbar^{2}}{m^{*} e^{2}}
$$

де $m^{*}$ - ефективна маса електрона.

В реальних пористих середовищах ми матимемо ділянки, які будуть об'єктами усіх вимірностей від 3 до 0. Таку система можна змоделювати феноменологічно ввівши дробову вимірність простору. Розглянемо зараз лише випадок високих концентрацій. Тоді густина станів такого електронного газу матиме вигляд:

$$
g(\varepsilon)=2 V_{D} \frac{\pi^{\frac{D}{2}}}{\Gamma\left(\frac{D}{2}\right)} \frac{(2 m)^{\frac{D}{2}}}{(2 \pi \hbar)^{D}} \varepsilon^{\frac{D}{2}-1}
$$

де $D$ - це дробова вимірність. Хімпотенціал при нулі температур буде рівним:

$$
\mu=\left(\frac{\Gamma\left(\frac{D}{2}\right)(2 \pi \hbar)^{D} D n}{\pi^{\frac{D}{2}}(2 m)^{\frac{D}{2}}}\right)^{\frac{2}{D}}
$$

а довжина екранування

$$
\lambda=\frac{4 \pi \hbar^{2} n^{\frac{2}{D}-1}}{m D e^{2}}\left(\Gamma\left(\frac{D}{2}\right) D\right)^{\frac{2}{D}}
$$

Вплив світла на довжину екранування матиме вигляд:

$$
\lambda=\frac{4 \pi \hbar^{2}\left(n+\gamma_{l} \Phi / \gamma p\right)^{\frac{2}{D}-1}}{m D e^{2}}\left(\Gamma\left(\frac{D}{2}\right) D\right)^{\frac{2}{D}} .
$$

Викладена нами теорія не враховує деформацію країв зон через поверхневі заряди.

\section{Магнітні властивості супрамолекулярних карбонів. Магнетоваріоністори}

Цікавим виявися і результат магнітних досліджень синтезованих карбонів. Усі вони в тій чи іншій мірі виявляють феромагнітні властивості (рис. 8, таблиця). Такий стан зумовлюється не стільки атомами вуглецю, скільки структурою пор. Певні дефекти такої структури приводять до різкого асиметричного піку густини станів на рівні Фермі [21]. При цьому остання має бути достатньо високою, що корелює з визначеним високим значенням диференціальної ємності. Очевидно, цікаво дізнатися чи впливає наявність магнітного моменту в нанопористому карбоні на параметри ємнісного накопичення енергії на межі його розділу з електролітом. Для відповіді на це питання комірки симетричної конфігурації з електродами на основі карбонів, синтезованих 3 $\gamma-C D$ та $\gamma-C D<F C>$ (див. таблицю) вимірювалися за нормальних умов та в постійному магнітному полі 
напруженістю 2,75 кОе. Виявилося, що для першого карбону у магнітному полі ємність не міняється, а для другого - зростає на 10 \%, що є в межах похибки експерименту.

Однак суттєві зміни в магнітному полі виявляє кінетика процесу накопичення заряду (рис. 9) і, відповідно, реактансні параметри, зокрема, тангенс кута електричних втрат. Саме в цьому сенсі можна говорити про магнетоваріоністори, тим більше, що сьогодні наявні прецизійні електронні схеми вимірювання реактансних параметрів.

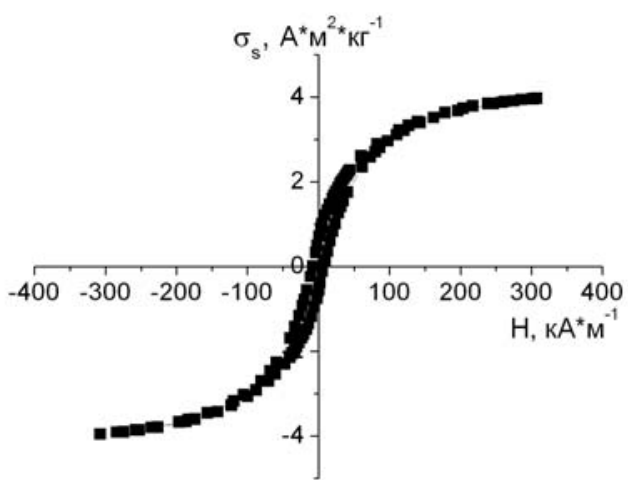

a

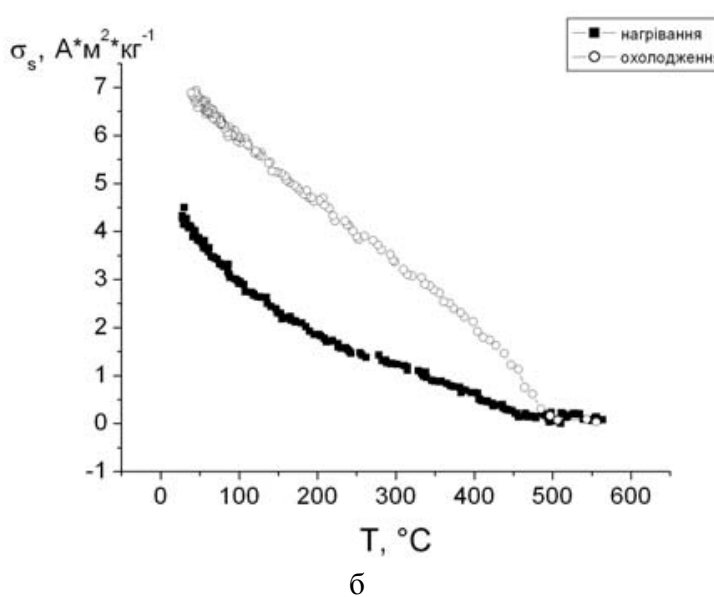

Рис. 8. Петля гістерезису вуглецю, отриманого піролізом $\gamma$-циклодекстрину при $800{ }^{\circ} \mathrm{C}$ (а) та температурна залежність його питомої намагніченості насичення

Таблиця

Результати магнітних досліджень синтезованих карбонів

\begin{tabular}{|c|c|c|c|c|}
\hline №п/ா & Зразок & Maca, $\Gamma$ & $\sigma_{\mathrm{s}}, \mathrm{A} \cdot \mathrm{M}^{2} \cdot \mathrm{\kappa}^{-1}$ & $\begin{array}{c}\text { Коерцитивна сила, } \\
\kappa A \cdot \mathrm{M}^{-1}\end{array}$ \\
\hline 1. & $\beta$-CD & 0,43 & 1,0 & 8 \\
\hline 2. & $\gamma-\mathrm{CD}$ & 0,41 & 4,5 & 8 \\
\hline 3 & $\beta$-CD<фероцен $>$ & 0,31 & 0,6 & 8 \\
\hline 4. & $\gamma-\mathrm{CD}<$ фероцен $>$ & 0.31 & 3,6 & 16 \\
\hline
\end{tabular}
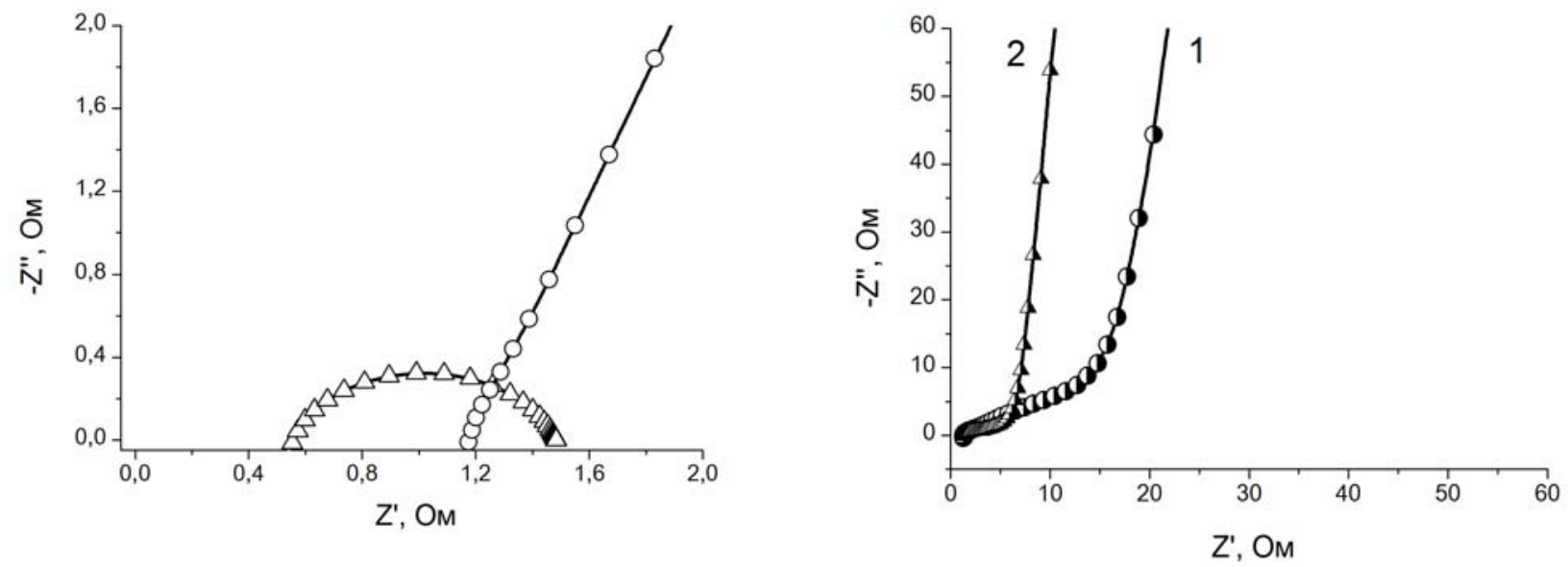

Рис. 9. Діаграми Найквіста для карбонів, синтезованих з $\gamma$-CD (ліворуч) та $\gamma$-CD $<\mathrm{FC}>$ (праворуч), побудовані для вимірів за нормальних умов (1) та в постійному магнітному полі напруженості 2,75 кОе (2)

\section{ВИСНОВКИ}

1. Синтезовано “кавітандне” вугілля володіє бімодальною пористою структурою 3 максимумами в розподілі пор за їхніми діаметрами в околі 1,3 та 4,3 нм. Загальна питома площа активної поверхні $\left(\mathrm{S}_{\text {акт }}\right) \beta$ циклодекстринового карбонізату порядку $72 \mathrm{~m}^{2} / \Gamma$. Активація водяною парою забезпечує питому ємність 50 Ф/г в симетричній конфігурації. Після КОН-модифікації вона в даній геометрії вимірів зростає до 158 Ф/г, а у від’ємній області потенціалів - від 101 до 203 Ф/г. 
2. Для $\gamma$-циклодекстринового карбону з практично “ідеальними” гальваностатичними циклами “заряд-

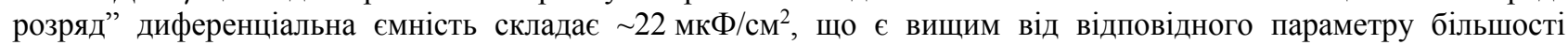
відомих видів активованого вугілля, що застосовуються в суперконденсаторах.

3. Для кавітатного карбону, синтезованого $3 \beta$-CD<фероцен $>$ питома ємність у від'ємній області потенціалів досягає 145 Ф/г при кулонівській ефективності $99 \%$. Для кавітатного карбону, синтезованого $3 \gamma$ $\mathrm{CD}<$ фероцен $>$ питома ємність падає у два рази, що найімовірніше пов'язано з різною комплементарністю фероцену до обидвох матриць.

4. У випадку полійодистого субстрату у $\beta$-CD зростання ємності для відповідного нанопористого карбону (після аналогічної “post”-модифікаціï) складає $\sim 10 \%$, набуваючи неординарних властивостей - його межа 3 30\%-водним розчином електроліту проявляє високу фоточутливість.

5. До КОН-модифікації даний кавітатний карбон характеризується ще вищою фоточутливістю: питома ємність на світлі зростає більш як в 4 рази, це пов'язано із збільшенням вкладу поверхневих станів у ємність області просторового заряду твердої фази.

6. Синтезовані кавітандні і кавітатні нанопористі карбони володіють феромагнітними властивостями. Суперконденсатори на їх основі можуть служити давачами слабкого магнітного поля за кімнатних температур, формуючи новий клас пристроїв - магнетоваріоністорів.

\section{ORCID IDs}

I.I. Grygorchak (i) https://orcid.org/0000-0003-3023-0803, A.K. Borisyuk (i) http://orcid.org/0000-0002-7674-4917, R.Ya. Shvets (i) https://orcid.org/0000-0002-4887-3105, D.V. Matulka (i) https://orcid.org/0000-0002-7065-4873,

O.I. Grygorchak (D) https://orcid.org/0000-0003-0668-1903

\section{СПИСОК ЛІТЕРАТУРИ}

[1]. B.E. Conway, Electrochemical Supercapacitors, (Plenum Publishing, New York, 1999), p. 698.

[2]. J.P. Zheng, in: Proceedings of the $14^{\text {th }}$ international seminar on double layer capacitors and hybrid energy storage devices, (Deerfield Beach, Florida, USA, 2004), pp. 142-154.

[3]. J.P. Zheng, T.R. Jow, J. Electrochem. Soc. 142(1), L6-L8 (1995).

[4]. D.A. McKeown, P.L. Hagans, L.P.L. Carette, A.E. Russell, K.E. Swider and D.R. Rolison, J. Phys. Chem. B. 103(23), 48254832 (1999).

[5]. B.E. Conway, H.A. Andreas, W.G. Pell in: Proceedings of the $14^{\text {th }}$ international seminar on double layer capacitors and hybrid energy storage devices, (Deerfield Beach, Florida, USA, 2004), pp. 155-176.

[6]. B.P. Bakhmatyuk, B.Ya. Venhryn, I.I. Grygorchak, Micov M.M. and Yu.O. Kulyk, Electrochimica Acta, 52, 6604-6610 (2007).

[7]. B.Ya. Venhryn, Z.A. Stotsko, I.I. Grygorchak, B.P. Bakhmatyuk and S.I. Mudry, Ultrasonic Sonochemistry, 20, 1302-1307 (2013).

[8]. B.Ya. Venhryn, Z.A. Stotsko, I.I. Grygorchak, S.I. Mudry and O.V. Balaban, Archives of Materials Science and Engineering. 52, 18-22 (2011).

[9]. K.D. Tovstjuk, I.I. Grigortchak, Z.D. Kovalyuk, I.D. Kozmik, V.V. Netyaga and B.P. Bahmatyuk, Int. Appl. No PST/US92/ 09245 (13 May, 1993).

[10]. J.-M. Len, Супрамолекулярная химия. Концепции и перспективы. [Supramolecular chemistry. Concepts and perspectives], (Novosibirsk, Science, 1998), p. 333. (in Russian)

[11]. D.V. Steed, J.L. Etwood, Супрамолекулярная химия. В двух томах. [Supramolecular chemistry. In two volumes], (Moscow: Akademkniga, 2007). Vol. 1. - p. 480, Vol. 2. - p. 416, (in Russian)

[12]. Z.B. Stoynov, B.M. Grafov, B. Savova-Stoynov and V.V. Elkin, Электрохимический импеданс. [Electrochemical impedance], (Moscow, Science, 1991), p. 336. (in Russian)

[13]. E. Barsoukov, J.R. Macdonald, Impedance spectroscopy. Theory, experiment and application. (Canada, Wiley interscience, 2005), p. 585.

[14]. A.I. Kondyr, A.K. Borysyuk, I.P. Pazdrii and S.G. Shvachko, Vibration in engineering and technology. 34(2), 41-43 (2004). (in Ukrainian)

[15]. H.C. Wang, B.L. Li, J.T. Li, B. Zhang and Z.X. Wan, Applied Surface Science. 257, 4325-4330 (2011).

[16]. G. Gryglewicz, J. Machnikowski, E. Lorenc-Grabowska, G. Lota and E. Frackowiak, Electrochimica Acta. 50(5), 1197-1206 (2005).

[17]. A. Harada, S. Takahashi, J. Chem. Soc. Chem. Commun. 10, 645-646 (1984).

[18]. A. Harada, K. Saeki and S. Takahashi, Organometallics. 8, 730-733 (1989).

[19]. M.O. Polumbrik, Ye.O. Kotlyar, H.V. Omelchenko, M.M. Polumbrik and V.M. Pasichny, Food Science and Technology. 10(3), 45-49 (2016). (in Ukrainian)

[20]. I.I. Grygorchak, A.K. Borysyuk, R.Ya. Shvets, F.O. Ivashchyshyn, N.T. Pokladok, V.I. Baluk, Yu.O. Kulyk, B.I. Rachiy, R.P. Lisovski and Yu.I. Sementsov, Physical surface engineering. 12(3), 412-427 (2014). (in Ukrainian)

[21]. T.L. Makarova, Semiconductors. 38(6), 615-638 (2004). (in Russian) 